\section{Evaluation of Blood Lead Level as a Risk Factor in Children with Autism Spectrum Disorder: A Case Control Study}

\author{
Ali MS ${ }^{1}$, Begum BA ${ }^{2}$, Akhter $\mathbf{S}^{3}$, Nigar $\mathrm{K}^{4}$, Urkan Uddin $\mathrm{KM}^{5}$, Akter $\mathbf{S}^{1}$ and Jolly $\mathrm{YN}^{1^{*}}$
}

${ }^{1}$ Upazila Health Complex, Netrakona, Bangladesh

${ }^{2}$ Atomic Energy Centre, Dhaka, Bangladesh

${ }^{3}$ Department of Pediatric Neurology, Bangabandhu Sheikh Mujib Medical University, Dhaka, Bangladesh

${ }^{4}$ Department of Obstetrics and Gynaecology, Mymensingh Medical College Hospital, Mymensingh, Bangladesh

${ }^{5}$ Department of Biochemistry, Holy Family Red Crescent Medical College, Dhaka, Bangladesh

*Corresponding author: Yeasmin Nahar Jolly, Chief Scientific Officer, Atomic Energy Centre, Atomic Energy Commission, Dhaka, Bangladesh Tel: 966 99 58; E-mail: jolly_tipu@yahoo.com

Received date: October 22, 2018; Accepted date: November 22, 2018; Published date: November 29, 2018

Copyright: @ 2018 Ali MS, et al. This is an open-access article distributed under the terms of the Creative Commons Attribution License, which permits unrestricted use, distribution, and reproduction in any medium, provided the original author and source are credited.

\begin{abstract}
The present study deals with the Evaluation of Blood lead $(\mathrm{Pb})$ level as a risk factor in Autistic Children and to determine the association between blood lead level (BLL) and Autism Spectrum Disorder (ASD). It was a casecontrol study. Blood samples were collected from both case (25 of 3-16 years) and control (25 of 3-16 years) groups by vein puncture for the determination of blood lead levels using Energy Dispersive X-ray Fluorescence (EDXRF) technique. Predesigned questionnaires were completed for each case and control group by interviewing the parents or care-givers. The present study revealed that there was a significant difference between mean ages of mother at child's birth in both case and control group. Significantly more children in case group had parents with higher educational levels and came from families with higher socioeconomic status. Significantly more children in ASD group came from urban areas than rural area. The risk of exposure to air pollution in case group was 14 times more than the control group which is represented by the proximity of child's residence to high traffic roads. History of pica was exclusively present in case group ( $p$ value 0.001 ) indicating that children in ASD group had more exposure to lead than those of control group. The mean blood levels were 44.18 and $29.22 \mu \mathrm{g} / \mathrm{dl}$ for case and control group respectively. In case group $48 \%$ of the children had blood lead level $\geq 10 \mu \mathrm{g} / \mathrm{dl}$ compared to $24 \%$ in the control group.
\end{abstract}

Keywords: Autistic; Blood lead level; Case group; Control group; EDXRF

\section{Introduction}

Autism is a devastating childhood condition that has emerged as an increasing social concern. It has increased in prevalence in recent decades. Environmental, genetic and epigenetic factors all play a role in determining the risk of autism. Toxic levels of heavy metals have been suggested to play a critical role in the pathogenesis of autism spectrum disorder (ASD). Several studies have evaluated associations between autism and biomarkers of heavy metal exposure and effects. The evidence that heavy metal exposure leads to an autistic phenotype is increasingly convincing. Sulfhydryl-reactive metals including arsenic, cadmium, lead, and mercury are the metals most commonly reported as being associated with autism prevalence and risk [1].

An emerging hypothesis states that autism may result from a combination of genetic susceptibility and exposure to environmental toxins at critical periods during brain development [2]. Several studies have explored the levels of heavy metals and essential minerals among children diagnosed with ASD [3]. Johnson \& Myers [4] suggested that environmental exposures may act as central nervous system teratogens in early gestational life. Among the toxic heavy metals lead is a pervasive environmental contaminant that can be ingested from various sources, including air pollution, lead paint and house dust contaminated by lead paint, as well as soil, drinking water and food.
Studies have the developing fetus and children are more sensitive to lead exposure than adults because of the immaturity of the blood-brain barrier, increased gastrointestinal absorption and hand-to-mouth behaviors. Several suggested the possible association between exposure to lead and ASD. Hence lead $(\mathrm{Pb})$ is a toxic metal shown to cause neuro developmental disorders in children [5]. Several studies have investigated the possible association between exposure to lead and ASD, but their findings are conflicting [6,7]. Adams et al. [8] conducted a study where they involved 55 children with autism ages 5-16 years compared to 44 controls of similar age and gender and reported that the autism group had significantly higher levels of lead in their red blood cells and higher urinary levels of lead, thallium, tin, and tungsten. Lead, thallium, tin, and tungsten are toxic metals that can impair brain development and function, and also interfere with the normal functioning of other body organs and systems.

Therefore, in a country like Bangladesh where there have been recent rapid urbanization and subsequent massive exposure of the children to numerous environmental pollution, it is important to find out an association between blood lead concentration and autism spectrum disorder (ASD). Limited data is available in our country evaluating blood lead level and ASD and hence present study was conducted to determine the blood lead level of children with ASD and that of controls and to compare the demographic characteristics of the patients with ASD \& that of controls. It was also elucidating whether lead is a risk factor in ASD or not. 


\section{Materials and Methods}

\section{Study population}

This is a case control study, carried out during the time period of July 2015 to June 2016. A total of 50 children were enrolled in this study. Among them 25 were diagnosed cases (Children of 3-16 years of age) of autism spectrum disorder (ASD) presenting to OPD, IPNA for follow up and 25 children (Children of 3-16 years of age ) who presented to OPD \& got admitted to inpatient department of Pediatrics, Bangabandhu Sheikh Mujib Medical University (BSMMU), Dhaka. Purposive sampling method was used in this study.

\section{Sample size}

Sample size was determined using sample size for hypothesis testing of the difference between two means (Equation 1) Hoque, et al. [9].

$(\mathrm{Z} \alpha+\mathrm{Z} \beta)^{2} \times\left(\Omega 1^{2}+\Omega 2^{2}\right)$

$\mathrm{n}=(\mu 1--\mu 2)^{2}$

where,

$\mathrm{n}=$ sample size for each group

$\mu 1=$ Mean of one group (Case group); $\Omega 1=$ SD of one group (Case group): from previous study.

$\mu 2=$ Mean of other group (Control group); $\Omega 2=$ SD of other group (Control group): from previous study.

$\mathrm{Z} a=\mathrm{Z}$-value of standard normal distribution (SND) at given level of significance.

$\mathrm{Z} \beta=\mathrm{Z}$-value of $\mathrm{SND}$ at a given power.

$\mathrm{Za}=$ Tow tailed $\mathrm{Z}$ - value of standard normal distribution at $95 \%$ confidence level which is 1.96 .

$\mathrm{Z} \beta=$ Two tailed $\mathrm{Z}$ - value of standard normal distribution at power of 0.80 (Type-II error $=0.20$ ) which is 0.84 .

Putting the values from previous study Rahbar et al. [5] in the equation (1) the sample size ' $n$ ' was estimated as:

$$
(1.96+0.84)^{2} \times\left(2.04^{2}+1.98^{2}\right)
$$

$n=$

$$
(3.84--2.31)^{2}
$$

$=27$

Therefore, 25 children were taken in each group, leading to total sample size of 50 children (Cases $=25$, Controls $=25$ ).

\section{Ethical consideration}

Ethical clearance was taken from Institutional Review Board (IBR) of BSMMU. The parents were informed about the study design and its objectives. They were explained that there would be no physical or social risk for the participants. They were also informed about freedom to participate or not to participate at any time. No incentive was given for participation. According to a predesigned questionnaires the demographic and socioeconomic data were collected from both case and control group.

\section{Data collection procedure}

The cases (ASD group) were collected from the outpatient department (OPD) of Institute of Pediatric Neuro disorder and Autism (IPNA), BSMMU who were previously diagnosed as having Autism Spectrum Disorder based (ASD) on the basis of 'Diagnostic and statistical manual of mental disorders, fourth edition, text revision (DSM-IV TR)' criteria. The controls were collected mainly from outpatient departments of Pediatrics and few were collected from inpatient department of Pediatrics who was admitted for conditions other than autism spectrum disorder (ASD) and who was not in serious conditions. Predesigned questionnaire were completed for each case and control by interviewing the parents or care-givers. Data were collected regarding demographic and socioeconomic status (SES) of the participants, information about parental educational levels. Information were collected about the children's potential exposure to lead through conditions of the households where the children were living in, through proximity of the child's home to a high traffic roads (whether or not the child's home was within a quarter of a mile of a high traffic road), and whether the child lived in a home that was located within a mile of automobile battery repair factory, automobile battery recycling centers, or battery processing facilities, through absence or presence of abnormal food habit, i.e., pica, sources of drinking water and through $\mathrm{H} / \mathrm{O}$ passive smoking of mothers during pregnancy and childhood.

\section{Collection and preparation of blood sample}

Blood samples were collected in numerically labeled plastic containers. Before collecting blood 50 plastic containers were pretreated in Atmospheric and Environmental Chemistry Laboratory of Atomic Energy Center, Dhaka. Containers were kept in 20\% Nitric acid for 24 hours. Then all were washed with tap water several times and finally rinsed with deionized water and dried. The empty weight of all containers were taken and kept in a plastic covering. Five $\mathrm{ml}$ of blood from each case \& control group was taken and kept in $-20^{\circ} \mathrm{C}$ in ultra-freezer in the Department of Biochemistry, BSSMU before transportation to the subsequent laboratory. Aseptic measures were followed strictly during collecting blood samples .The samples were dried in an oven at $60^{\circ} \mathrm{C}-70^{\circ} \mathrm{C}$ until constant weight was obtained. The dried mass were powdered in a carbide mortar with the help of a pestle and preserved in a desiccator until subsequent analysis. For the preparation of pellet $0.1 \mathrm{~g}$ of each of powdered sample was pressed into a pellet of $0.7 \mathrm{~cm}$ diameter and $1 \mathrm{~mm}$ thickness using a pellet maker (CARVER, $10 \mathrm{~mm}$, model no:018735C) using 3 ton pressure. All samples were analyzed for lead $(\mathrm{Pb})$ concentration using $\mathrm{X}$-ray Fluorescent (XRF) Spectrometry.

\section{Sample irradiation}

The sample pellet was irradiated with $30 \mathrm{mCi} \mathrm{Cd}-109$ radioisotope annular source for about 1000 seconds to excite the characteristic Xrays of the elements present in the sample. The X-rays were detected with the $\mathrm{Si}(\mathrm{Li})$ detector of $170 \mathrm{eV}$ resolution. The X-ray spectrum of each sample was collected by a multichannel analyzer and transferred to a computer for storage, processing and evaluation of the net X-ray intensities. Thus the concentration of blood lead was measured from the sample $[10,11]$. The method validation was carried out by constructing a calibration curve using commercially available standard material (Apple Leaf/NIST 1516, Spinach/NIST 1570a, Tomato Leaf/ NIST 1573a, Peach Leaf/NIST 1574) and checking the relevant elemental concentration trough analysis of a standard reference 
Citation: $\quad$ Ali MS, Begum BA, Akhter S, Nigar K, Urkan Uddin KM, et al. (2018) Evaluation of Blood Lead Level as a Risk Factor in Children with Autism Spectrum Disorder: A Case Control Study . J Blood Disord Transfus 10: 1000415. doi:10.4172/2155-9864.1000415

Page 3 of 8

material (Orchard Leaf/NIST 1571). The whole method was described elsewhere [12].

\section{Statistical analysis}

The obtained data were checked, verified and analyzed by Statistical Package for Social Sciences (SPSS, version 22). Data were expressed as frequency, percentage, range, mean, median and standard deviation $( \pm \mathrm{SD})[13,14]$. Mann-Whitney $\mathrm{U}$ test, unpaired student's t-test, Chisquare test, Fisher's exact test were performed to evaluate the association between the variables and a p-value $\leq 0.05$ was accepted as level of significance at a $95 \%$ confidence interval $(95 \% \mathrm{CI})$.

\section{Result and Discussion}

\section{Analysis of demographic and socioeconomic data}

\section{Distribution of age and sex of the study children}

Among the total 50 children, the ASD group (25) had a mean age of 8.83 years, range $3-16$ ( 14 are 3 to 10 and 11 are 10 to 16 ) while the mean age for children in the control group (25) was 10.80 years, range 3-16 (10 are 3 to 10 and 15 are 10 to 16$)$ respectively. There was no statistically significant difference ( $p$ value 0.105 ) between ASD and control groups regarding age distribution. In case of sex, among the total 25 children in the ASD group, 80\% were male and $20 \%$ were female.
Among 25 children in the control group, $56 \%$ was male and $44 \%$ was female. There was no statistically significant difference ( $\mathrm{p}$ value 0.069 ) between ASD and control groups regarding sex distribution. But in the ASD group the ratio between male and female was 4:1

\section{Effect of maternal ages and monthly family income at child's birth}

The findings are showed in (Table 1) and revealed that the mean age of the mothers in case group was higher than that of control group which was statistically significant. This age distribution signifies that high maternal age is a risk factor for autism.

Table 2 shows that the majority (92\%) of children in case group was from high income group. Socioeconomic status was significantly different between the two groups. This observation is consistent with the study conducted by Rahbar et al. [5] and Durkin et al. [15]. Higher socioeconomic status in children with ASD and probable explanation between the increased [16,17] incidence of autism and higher socioeconomic status (SES) might be that there may be a possibility of higher exposures of some consumer products which may act as environmental teratogens [18].

\section{Effect of educational status of parents by groups}

The educational level of the parents by the group is shown in Table 3. From Table 3 it was evident that educated families were significantly more in case group than the control group [19-23].

\begin{tabular}{|l|l|l|l|}
\hline \multirow{2}{*}{ Maternal ages at child's birth (years) } & Group & & p value* \\
\cline { 2 - 4 } & Case & Control & N (\%) \\
\cline { 2 - 4 } & $\mathrm{N}(\%)$ & $25(100.0)$ & \\
\hline$\leq 35$ & $24(96.0)$ & $0(.0)$ & $25(100.0)$ \\
\hline$>35$ & $1(4.0)$ & $25(100.0)$ & $23.44 \pm 5.44$ \\
\hline Total & $27.13 \pm 4.79$ & & $0.014 \mathrm{~s}$ \\
\hline Mean \pm SD $(y)$ & & \\
\hline *t test was done to measure the level of significance. S: Significant & & \\
\hline
\end{tabular}

Table 1: Comparison of maternal ages at child's birth by groups $(n=50)$.

\begin{tabular}{|l|l|l|l|l|l|}
\hline \multirow{2}{*}{ Family income (Tk.) } & Group & & \multirow{2}{*}{ Odds Ratio } & 95\% Cl of Odds Ratio & \multirow{2}{*}{ p value* } \\
\cline { 1 - 4 } & Case & Control & $\mathrm{N}(\%)$ & & \\
\cline { 1 - 4 } & $\mathrm{N}(\%)$ & $11(44)$ & 14.64 & $2.82-75.95$ & \\
\hline$>25000$ & $23(92)$ & $14(56)$ & & \\
\hline$\leq 25000$ & $2(8)$ & $25(100)$ & & \\
\hline Total & $25(100)$ & & \\
\hline${ }^{*}$ Chi square test was done to measure the level of significance. Cl: Confidence Interval. S: Significant & \\
\hline
\end{tabular}

Table 2: Comparison of the family income per month by groups $(n=50)$ 
Citation: $\quad$ Ali MS, Begum BA, Akhter S, Nigar K, Urkan Uddin KM, et al. (2018) Evaluation of Blood Lead Level as a Risk Factor in Children with Autism Spectrum Disorder: A Case Control Study . J Blood Disord Transfus 10: 1000415. doi:10.4172/2155-9864.1000415

Page 4 of 8

\begin{tabular}{|c|c|c|c|c|c|}
\hline \multirow{3}{*}{ Educational levels of fathers } & Group & & \multirow{3}{*}{ Odds Ratio } & \multirow{3}{*}{$95 \% \mathrm{Cl}$ of Odds Ratio } & \multirow{3}{*}{$p$ value } \\
\hline & Case & Control & & & \\
\hline & $\mathrm{N}(\%)$ & $\mathrm{N}(\%)$ & & & \\
\hline HSC and above & $20(80)$ & $4(16)$ & 21 & $4.92-89.56$ & $0.001 \mathrm{~s}$ \\
\hline Up to SSC & $5(20)$ & $21(84)$ & & & \\
\hline Total & $25(100)$ & $25(100)$ & & & \\
\hline \multicolumn{6}{|l|}{ Education levels of mothers } \\
\hline HSC and above & $19(76)$ & $3(12)$ & 23.22 & $5.10-105.73$ & $0.001 \mathrm{~s}$ \\
\hline Up to SSC & $6(24)$ & $22(88)$ & & & \\
\hline Total & $25(100)$ & $25(100)$ & & & \\
\hline
\end{tabular}

Table 3: Comparison of the Parental educational levels by groups ( $\mathrm{n}=50$ )also found statistically different in the present study (Table 3) which is consistent with a previous study done by Hertz-Picciotto et al. [21], Meter et al. [24] and Rahbar et al. [5]. It may be assumed that parents with higher educational status belong to higher socioeconomic status that further increases the possibility of exposing the children to more environmental teratogens in the form of consumer products $[25,26]$.

Distribution of the places of birth, residence, proximity to

High traffic road of the children by groups

\begin{tabular}{|c|c|c|c|c|c|}
\hline \multirow{3}{*}{ Observations } & Group & & \multirow{3}{*}{ Odds Ratio } & \multirow{3}{*}{$95 \% \mathrm{Cl}$ of Odds Ratio } & \multirow{3}{*}{ p value* } \\
\hline & Case & Control & & & \\
\hline & $N(\%)$ & $\mathrm{N}(\%)$ & & & \\
\hline \multicolumn{6}{|l|}{ Place of Birth } \\
\hline Urban & $20(80)$ & $8(32)$ & 8.5 & $2.34-30.91$ & $0.001 \mathrm{~s}$ \\
\hline Rural & $5(20)$ & $17(68)$ & & & \\
\hline \multicolumn{6}{|c|}{ Place of Residence } \\
\hline Dhaka & $8(32)$ & $10(40)$ & 0.71 & $0.22-2.25$ & 0.556 \\
\hline Outside & $17(68)$ & $15(60)$ & & & \\
\hline \multicolumn{6}{|c|}{ Proximity to high traffic road } \\
\hline Yes & $23(92)$ & $11(44)$ & 14.64 & $2.82-75.95$ & $0.001 \mathrm{~s}$ \\
\hline No & $2(8)$ & $14(56)$ & & & \\
\hline \multicolumn{6}{|c|}{ Passive smoking } \\
\hline Yes & $10(40.0 \%)$ & $1(4.0 \%)$ & 16 & $1.86-137.97$ & $0.002 \mathrm{~s}$ \\
\hline No & $15(60.0 \%)$ & $24(96.0 \%)$ & & & \\
\hline
\end{tabular}

Table 4: Distribution of different variables by groups ( $n-50)$

This observation is consistent with Mullick et al. [27] and Rahbar et al. [5]. It was observed that places of birth of the studied children followed a statistically significant distribution between ASD and control groups (Table 4) [27-30]. Most of the children in ASD group came from urban areas $(80 \%)$.

Mitra et al. [30] found that blood lead levels at the urban industrial area were significantly higher than those at the rural areas. In this 
study among the case group 32\% of children came from Dhaka and 68 $\%$ from outside Dhaka whereas among the control group $40 \%$ of children came from Dhaka \& $60 \%$ came from outside Dhaka which indicated that living in Dhaka seemed not to be a risk factor for developing autism [31,32].

Kaiser et al. [33] identified that mean blood lead level in children at five primary schools in Dhaka was above the CDC's level of concern $(10 \mu \mathrm{g} / \mathrm{dl})[34,35]$. Despite reduction in airborne lead associated with the phasing out of lead-based fuels, soil near roads and freeways is still contaminated with lead dust Mendola et al. [36].

In this study a positive relationship was found between proximity of residence to freeways [37-41] and major roadways ( $\leq 400$ meters) during pregnancy and postnatal period and ASD (Table 4) which is consistent with Volk et al. [39].

In another study Volk et al. [42] found that Children with autism were more likely to live at residences having highest exposure to trafficrelated air pollution, during gestation compared with control children.

Maternal active and passive cigarette smoking is associated with lower global intelligence, impaired visuospatial functioning, and lower language $[43,44]$ and reading scores Mendola et al. [36]. Maternal smoking has also been implicated as a risk factor for idiopathic mental retardation Drews et al. [45]. In the present study history of passive smoking during pregnancy $[46,47]$ and postnatal period was identified in mothers of $10(40 \%) \& 1(4 \%)$ children in ASD and control groups respectively (Table 4). This observation is supported by the previous studies by Fried et al. [48] and Blaurock-Busch et al. [49]. History of active smoking was found neither in ASD nor in control group which is possibly consistent with our cultural background. It is expected that future researchers will focus on conducting research with larger sample to explore the definite association between exposure to lead and autism spectrum disorder.

\section{Distribution of home environment (House with paint peeling or chipping off), sources of drinking water, presence of pica by groups $(\mathbf{n}=\mathbf{5 0})$}

From Table 5, it was evident that proximity of residence to freeways and major roadways ( $\leq 400$ meters) in case group was significant compared to control group (p-value 0.001 ). This observation indicates that the children in ASD group had more exposure to air pollution than those of control group.

\begin{tabular}{|c|c|c|c|}
\hline \multirow{3}{*}{ Variables } & \multicolumn{2}{|l|}{ Group } & \multirow[t]{3}{*}{ p value* } \\
\hline & Case & Control & \\
\hline & $\mathrm{N}(\%)$ & $\mathrm{N}(\%)$ & \\
\hline \multicolumn{4}{|c|}{ House with paint peeling or chipping off } \\
\hline Yes & $4(16.0)$ & $0(.0)$ & ${ }^{*} 0.110 \mathrm{~ns}$ \\
\hline No & $21(84.0)$ & $25(100.0)$ & \\
\hline \multicolumn{4}{|c|}{ Sources of drinking water } \\
\hline Piped water & $11(44)$ & $6(24)$ & ${ }^{\star \star} 0.136 \mathrm{~ns}$ \\
\hline Tube-well water & $14(56)$ & $19(76)$ & \\
\hline \multicolumn{4}{|l|}{ Presence of pica } \\
\hline Yes & $12(48)$ & $0(0)$ & ${ }^{* *} 0.001 \mathrm{~s}$ \\
\hline No & $13(52)$ & $25(100)$ & \\
\hline
\end{tabular}

Table 5: Distribution of home environment (House with paint peeling or chipping off), sources of drinking water, presence of pica by groups $(\mathrm{n}=50)$

History of living in houses with paint peeling \& chipping off in ASD compared to control group $(\mathrm{p}=0.110)$. Cracked, peeling or chalking paint can expose children to lead exposure through contact with dust or pica [36]. Home environment was evaluated in the present study (Table 2). It was found no statistically significant difference (Table 5) between the two groups regarding home environment which is consistent with a recent study by Rahbar et al. [5]. Piped water and tube well water as sources of drinking water were evaluated in both ASD and control groups in this study (Table 5) and [50,51] hence showed no significant difference between the two groups, which is consistent with a previous study by Rahbar et al. [5]. This may be due to the fact that children are still being exposed to lead through drinking water service lines made from lead, lead solder, or plumbing materials as it is transported from its source into homes. Lead also leaches into tap water through the corrosion of plumbing materials Brown and Margolis [52]. Table 5 shows that $48 \%$ of children in case group had pica, whereas in control group no children had pica which was statistically significant. This indicates that children in ASD group had more exposure to lead than those of control group.

Children with autism are at increased risk for lead exposure and intoxication because of exploratory oral behaviors and pica Clark et al. [53]. In the present study history of pica was present in 12 (48\%) children in the ASD group [54-58] and none in the control group (Table 5). Our finding of high incidence of pica was supported by the studies of Clark et al. [53] and Rahbar et al. [5]. Mishori [59] suggested 
checking serum lead levels in children who engage in geophagia since dirt may contain lead.

\section{Effect of Blood lead $(\mathrm{Pb})$ level in groups}

Mean blood lead levels in ASD group was $44.18 \mu \mathrm{g} / \mathrm{dl}$, whereas mean blood lead levels in control group was $29.22 \mu \mathrm{g} / \mathrm{dl}[60,61]$.
Difference in blood lead levels between two groups was not statistically different, though both groups have mean blood lead levels above the CDC's level of concern $(10 \mu \mathrm{g} / \mathrm{dl})$ (Table 6).

\begin{tabular}{|l|l|l|l|}
\hline \multirow{2}{*}{ Blood leads level of child } & Group & \multicolumn{2}{|l|}{ p value $^{*}$} \\
\cline { 2 - 4 } & Case & Control & \multirow{2}{*}{$0.158 \mathrm{~ns}$} \\
\hline Mean $(\mu \mathrm{g} / \mathrm{dl})$ & 44.18 & 29.22 & \\
\hline Range $(\mu \mathrm{g} / \mathrm{dl})$ & $1.20-177.00$ & $1.20-192.00$ & \\
\hline Median & 1.2 & 1.2 & \\
\hline Mean Rank & 28 & 23 & \\
\hline $\mathrm{n}$ & 25 & 25 & \\
\hline *Mann-Whitney U test was done to measure the level of significance. NS: Not significant. & & \\
\hline
\end{tabular}

Table 6: Comparison of mean blood lead levels in case and control groups $(n=50)$.

In the present study mean blood lead level in the ASD group was higher than the control group, though statistically not significant (Table 6). This observation is consistent with several other studies Fido and Al-Saad [62], Blaurock-Busch et al. [49], Priya and Geetha [63], Al-Farsi et al. [3], El-Ansary et al. [64] and Alabdali et al. [2]. Tian et al. [27] found no significant differences in blood lead levels between case and control groups. In a study Hossain [65] found that heavy metal exposure had significant impact on increased risk of autism. Furthermore, in the present study it was found that the mean blood lead level in both case and control groups was above the threshold level $(10 \mu \mathrm{g} / \mathrm{dl})$ suggested by Centers for Disease Control and Prevention's (CDC). In the current study there was no significant difference was found when blood lead level above the CDC's level of concern $(10 \mu \mathrm{g} / \mathrm{dl})$ was compared between case and control groups (Table 6) which is in contrast with the study by Tian et al. [66] where no blood lead level was found higher than $10 \mu \mathrm{g} / \mathrm{dl}$ in any subject. On the other hand, Kern et al. [67], Yorbik et al. [68] and Rahbar et al. [5] reported lower levels of lead in children with ASD compared with typically developing (TD) controls.

\section{Conclusion}

In the search for pieces to the autism puzzle, a growing number of people in the autism community have turned their attention to the possible role of heavy metals specially Lead $(\mathrm{Pb})$. Gene-environment interaction has long been considered a likely mechanism contributing to the risk for autism spectrum disorder (ASD). Some symptoms and behaviors observed in Autism Spectrum Disorders appear to parallel those seen in heavy metal $(\mathrm{Pb})$ toxicity, eg. in chronic lead poisoning which include loss of appetite, apathy, irritability, refusal to play, constipation, decreased intelligence, hyperactivity, aggression, poor impulse control, poor eye-hand coordination, and impaired motor skill development.

Children come in contact with toxic heavy metals through inhalation, ingestion and absorption. Exposure may occur through air, water, food, or consumer products, e.g. tap water which may leach lead from pipes and solder old paint chips- particularly for children with pica; candles with lead core wicks; leaded gasoline \& poorly monitored lead emissions via industrial waste disposal, antique pewter and ceramic wares, pesticides and insecticides, disposed batteries, pottery, and cans. As children of Bangladesh are exposed to different sources of lead poisoning mentioned above, it is reasonable to identify whether or not elevated blood lead level is a risk factor for Autism Spectrum Disorder.

In the present study, the mean blood lead level in the case (ASD) group was higher than the control group and hence $48 \%$ children belong to case group had Blood lead $(\mathrm{Pb})$ level $\geq 10 \mu \mathrm{g} / \mathrm{dl}$, whereas in control group it is $24 \%$. Significantly more children in ASD group came from families with higher socio-economic status and urban areas than rural areas which reflects more exposure to Lead $(\mathrm{Pb})$ in the form of consumer products. It was also found the risk of exposure to air pollution in case group is 14 times more than the control group. $\mathrm{Pb}$ is an airborne particle thus more exposure to air pollution leads children more prone to lead $(\mathrm{Pb})$ contamination. As children with ASD may have a poor heavy-metal-detoxifying mechanism and cannot excrete lead from their bodies compared to healthy children, elevated blood lead level seems a risk factor for the development of autism spectrum disorder.

The mean blood lead level was higher in both groups than the recommended level by the CDC which emphasizes the magnitude of the exposure to lead and thus placing children of our country at risk of abnormal neurodevelopment. Several risk factors were found which might be associated with ASD e.g. the children from families with higher socioeconomic status, parents with higher educational levels and age of parents, living in urban areas, proximity of child's residence to high traffic roads, history of pica, exposure to passive smoking in mothers during pregnancy and postnatal period, which are also found in the children with high blood lead $(\mathrm{Pb})$ level. From this point of view it is quite evident that high lead level is a risk factor for Autism Spectrum Disorder (ASD). It can be suggested that to identify the definite association between blood lead level and autism spectrum disorder, further study with larger sample size should be carried out. The mean blood lead levels in both the studied groups were higher 
than the CDC's recommended level of $<10 \mu \mathrm{g} / \mathrm{dl}$ that reflects the high environmental exposures to lead poisoning in our country. Therefore, universal screening of infants and young children for lead exposure should be initiated.

\section{Conflict of Interest}

The authors declare that there is no conflict of interest regarding the publication of this paper.

\section{Acknowledgement}

The authors appreciated the help and association of the stuff members of Atmospheric and Environmental Chemistry Laboratory, Chemistry Division, Atomic Energy Centre, Dhaka and Bangabandhu Sheikh Mujib Medical University (BSMMU), Dhaka.

\section{References}

1. Dietert RR, Dietert JM, DeWitt JC (2011) Environmental risk factors for autism. Emerg Health Threats J 4: 1-11.

2. Alabdali A, Al-Ayadhi L, El-Ansary A (2014) A key role for an impaired detoxification mechanism in the etiology and severity of autism spectrum disorders. Behav Brain Funct 10: 14.

3. Al-Farsi YM, Waly MI, Al-Sharbati MM, Al-Shafaee MA, Al-Farsi OA, et al. (2012) Levels of heavy metals and essential minerals in hair samples of children with autism in Oman: A case-control study. Biol Trace Elem Res 151: 181-186.

4. Johnson CP, Myers SM (2007) Identification and evaluation of children with autism spectrum disorders. Pediatrics, vol. 120: 1183-1215.

5. Rahbar MH, Samms-Vaughan M, Loveland KA, Pearson DA, Bressler J, et al. (2012) Maternal and paternal age are jointly associated with childhood autism in Jamaica. J Autism Dev Disord 42.

6. Arberas C, Ruggieri V (2013) Autism and epigenetics. A model of explanation for the understanding of the genesis in autism spectrum disorders. Medicina (B Aires) 73: 20-29.

7. Begum BA, Biswas SK (2005) Quality assurance test for trace element analysis in Marine Sediment using radioisotope induced XRF. Nucl Sci Appl 14: 57-62.

8. Adams JB, Audhya T, McDonough-Means S, Rubin RA, Quig D, et al. (2012) Toxicological status of children with autism vs. neurotypical children and the association with autism severity. Biol Trace Elem Res 151: 171-180.

9. Hoque MM (2014) Abc of research methodology \& biostatistics, Asian Color Printing, Dhaka.

10. Bradstreet J, Geier DA, Kartzinel JJ, Adams JB, Geier MR, et al. (2003) A case-control study of mercury burden in children with autistic spectrum disorders. Am Physicians Surg 8: 76-79.

11. Brugha TS, McManus S, Bankart J, Scott F, Purdon S, et al. (2011) Epidemiology of autism spectrum disorders in adults in the community in England. Arch Gen Psychiatry 68: 459-466.

12. Khan FE, Jolly YN, Rabiul GM, Akter S, Kabir J, et al. (2014) Contamination status and health risk assessment of trace elements in food stuffs collected from the Buriganga River embankments, Dhaka, Bangladesh. Int Jour of Food Contamination 1.

13. Bowers K, Erickson C (2014) Gene-environment interaction and autism spectrum disorder. OA Autism 2: 1-5.

14. CDC (2014) Prevalence of Autism Spectrum Disorder Among Children Aged 8 Years-Autism and Developmental Disabilities Monitoring Network, 11 sites, United States, 2010. MMWR 63: pp.1-21.

15. Durkin MS, Maenner MJ, Meaney FJ, Levy SE, DiGuiseppi C,et al. (2010) Socioeconomic inequality in the prevalence of autism spectrum disorder: Evidence from a US. cross-sectional study. PLoS ONE 5:11551.

16. www.cdc.gov/ncbddd/autism/documents/community_report_autism.pdf
17. Frisbie SH, Ortega R, Maynard DM, Sarkar B (2002) The Concentrations of arsenic and other toxic elements in Bangladesh's drinking water. Environ Health Perspect 110: 1147-1153.

18. Bhasin TK, Schendel D (2007) Sociodemographic risk factors for autism in a US metropolitan area. J Autism Dev Disord 37: 667-677.

19. Garrecht M, Austin DW (2011) The plausibility of a role for mercury in the etiology of autism: a cellular perspective. Toxicol Environ Chem 93: 1251-1273.

20. Giarelli E, Wiggins LD, Rice CE, Levy SE, Kirby RS, et al. (2010) Sex differences in the evaluation and diagnosis of autism spectrum disorders among children. Disabil Health J 3: 107-116.

21. Hertz-Picciotto I, Green PG, Delwiche L, Hansen R, Walker C, et al. (2010) Blood mercury concentrations in charge study children with and without autism. Environ Health Perspect 118: 161-166.

22. Grafodatskaya D, Chung B, Szatmari P, Weksberg R (2010) Autism spectrum disorders and epigenetics. J Am Acad Child Adolesc Psychiatry 49: 794-809.

23. Hallmayer J (2011) Genetic heritability and shared environmental factors among twin pairs with autism. J Arch Gen Psychiatry 68: 1095.

24. Meter KCV, Christiansen LE, Delwiche LD, Azari R, Carpenter TE, et al. (2010) Geographic distribution of autism in California: A retrospective birth cohort analysis Autism Research 3: 19-29.

25. Hirtz DG, Wagner A, Filipek PA (2012) Swaiman's Pediatr Neurol (5th edn), Saunders. Elsevier.

26. Hossain MSW (2011) Solving the autism public health puzzle: Regional and international collaboration', Excerpt of the paper of Ms Saima Wazed Hossain, Chair of the National Advisory Committee on Autism in Bangladesh, United Nations Head Quarters.

27. Mullick MSI, Goodman R (2005) The prevalence of psychiatric disorders among 5-10 year olds in rural, urban and slum areas in Bangladesh: An exploratory study. Soc Psychiatry Psychiatr Epidemiol 40: 663-671.

28. Kim YS, Leventhal BL, Koh YJ, Fombonne E, Laska E, Lim EC et al. (2011) Prevalence of autism spectrum disorders in a total population sample Am J Psychiatry 168: 904-912.

29. Kinney DK, Daniel H, Barcha DH, Chayka B, Napoleona SS, et al. (2010) Environmental risk factors for autism: Do they help cause De Novo genetic mutations that contribute to the disorder? Med Hypotheses 74: 102-106.

30. Mitra AK, Haque A, Islam M, Bashar SAMK (2009) Lead poisoning: An Alarming public health problem in Bangladesh Int J Environ Res Public Health 6: 84-95.

31. Kogan MD, Blumberg SJ, Schieve LA, Boyle CA, Perrin KS, et al. (2009) Prevalence of parent-reported diagnosis of autism spectrum disorder among children in the US, 2007 Pediatrics 124: 1395-1403.

32. Lawler CP, Croen LA, Grether JK, Van de Water J (2004) Identifying environmental contributions to autism: provocative clues and false leads Ment Retard Dev Disabil Res Rev 10: 292-302..

33. Kaiser R, Henderson AK, Daley WR, Naughton M, Khan MH (2001) Blood lead levels of primary school children in Dhaka, Bangladesh. Environmental Health Perspectives 109: 563-566.

34. Lidsky TI, Schneider JS (2005)'Autism and autistic symptoms associated with childhood lead poisoning J Appl Res 5: 80-87

35. Loke YJ, Hannan AJ, Craig JM (2015) The role of epigenetic change in autism spectrum disorders Front Neurol 119: 873-77.

36. Mendola P, Selevan SG, Gutter S, Rice D (2002) Environmental factors associated with a spectrum of neurodevelopmental deficits mental retardation and developmental disabilities research reviews 8: 188-197.

37. MOHFW (2013) Survey of autism and Neurodevelopmental Disorders in Bangladesh: Report pp. 1-166.

38. Mondol MN, Khaled M, Chamon AS, Ullah SM (2014) Trace metal concentration in atmospheric aerosols in some city areas of Bangladesh. Bangladesh J Sci Ind Res 49: 263-270.

39. Volk HE, Hertz-Picciotto I, Delwiche L, Lurmann F, McConnell R, et al. (2011) Residential proximity to freeways and autism in the charge study. Environ Health Perspect 119: 873-877. 
Citation: $\quad$ Ali MS, Begum BA, Akhter S, Nigar K, Urkan Uddin KM, et al. (2018) Evaluation of Blood Lead Level as a Risk Factor in Children with Autism Spectrum Disorder: A Case Control Study . J Blood Disord Transfus 10: 1000415. doi:10.4172/2155-9864.1000415

Page 8 of 8

40. Newschaffer CJ, Croen LA, Fallin MD, Hertz-Picciotto I, Nguyen DV, et al. (2012) Infant siblings and the investigation of autism risk factors. J Neurodev Disord 4: 1-16.

41. Parner EH, Baron-Cohen S, Lauritsen MB, Jørgensen M, Schieve LA, et al. (2012) Parental age and autism spectrum disorders. Ann Epidemiol 22: 143-150.

42. Volk HE, Lurmann F, Penfold B, Hertz-Picciotto I, McConnell (2013) Traffic-related air pollution, particulate matter, and autism. Arch Gen Psychiatry 70: 71-77.

43. Rabbani MG, Alam MF, Ahmed HU, Sarkar M, Islam MS, et al. (2009) Prevalence of mental disorders, mental retardation, epilepsy and substance abuse in children. Bangladesh J Psychiatry 23.

44.

45. Drews CD, Murphy CC, Yearing-Allsopp M, Decoufle P (1996) The relationship between idiopathic mental retardation and smoking during pregnancy. Pediatrics 97: 547-553.

46. Rahbar MH, Samms-Vaughan M, Dickerson AS, Loveland KA, Ardjomand-Hessabi M, et al. (2015) Blood lead concentrations in Jamaican children with and without autism spectrum disorder. Int J Environ Res Public Health 12:83-105.

47. Rahman MM (2010) Autism spectrum disorders. J Bangladesh Coll Phys Surg 28: 143-144

48. Fried PA, Watkinson B, Siegel LS (1997) Reading and language in 9- to 12-year olds prenatally exposed to cigarettes and marijuana. Neurotoxicol Teratol 19: 171-183.

49. Blaurock-Busch E, Amin OR, Rabah T (2011) Heavy metals and trace elements in hair and urine of a sample of arab children with autistic spectrum disorder. J Clin Med 6: 247-257.

50. Raviola GJ, Trieu ML, DeMaso DR, Walter HJ (2016) Nelson textbook of pediatrics. Elsevier.

51. Reichenberg A, Gross R, Weiser M, Bresnahan M, Silverman J, et al. (2006) Advancing paternal age and autism. Arch Gen Psychiatry 63: 1026-1032.

52. Brown MJ, Margolis S (2012) Lead in drinking water and human blood lead levels in the United States. MMWR 61: 1-9.

53. Clark B, Vandermeer B, Simonetti A, Buka I (2010) Is lead a concern in Canadian autistic children?. Paediatr Child Health 15: 17-22.

54. Roberts EM, English PB, Grether JK, Windham GC, Somberg L (2007) Maternal residence near agricultural pesticide applications and autism spectrum disorders among children in the California Central Valley. Environ Health Perspect 115, 1482-1489.
55. Schaefer GB, Mendelsohn NJ (2013) Clinical genetics evaluation in identifying the etiology of autism spectrum disorders. Genet Med 15: 399-407.

56. Fido A, Al-Saad S (2005) Toxic trace elements in the hair of children with autism. Autism 9: 290-298.

57. Solon O, Riddell TJ, Quimbo SA, Butrick E, Aylward GP (2008) Associations between cognitive function, blood lead concentration, and nutrition among children in the Central Philippines. J Pediatr 152: 237-243.

58. Tordjman S, Somogyi E, Coulon N, Kermarrec S, Cohen D (2014) Genexenvironment interactions in autism spectrum disorders: Role of epigenetic mechanisms. Front Psychol 5:1-17.

59. Mishori R (2014) 'Pica: An age-old eating disorder that's often missed. The Journal of Family Practice 63: 1-4.

60. WHO (2013) Autism spectrum disorders \& other developmental disorders: From raising awareness to building capacity.

61. Windham GC, Zhang L, Gunier R, Croen LA, Grether JK (2006) Autism spectrum disorders in relation to distribution of hazardous air pollutants in the San francisco bay area. Environ Health Perspect 114: 1438-1444.

62. Fido A, Al-Saad S (2005) Toxic trace elements in the hair of children with autism. Autism 9: 290-298.

63. Priya MDL, Geetha A (2011) Level of trace elements (copper, zinc, magnesium and selenium) and toxic elements (lead and mercury) in the hair and nail of children with autism. Bio Trace Elem Res 142: 148-158.

64. Al-Farsi YM, Waly MI, Al-Sharbati MM, Al-Shafaee MA, Al-Farsi OA, et al. (2012) Levels of heavy metals and essential minerals in hair samples of children with autism in Oman: A case-control study. Biol Trace Elem Res 151: $181-186$

65. Hossain MM (2010) Assessment of risk factors for autistic child' [Thesis], Unpublished.

66. Tian Y, Green PG, Stamova B, Hertz-Picciotto I, Pessah IN, et al. (2011) Correlations of gene expression with blood lead levels in children with autism compared to typically developing controls. Neurotox Res 19: 1-13.

67. Kern JK, Grannemann BD, Trivedi MH, Adams JB (2007) Sulfhydrylreactive metals in autism. J Toxicol Environ Health A 70: 715-721.

68. Yorbik O, Kurt I, Haşimi A, Oztürk O (2010) Chromium, cadmium, and lead levels in urine of children with autism and typically developing controls. Biol Trace Elem Res 135: 10-15. 